\title{
The impact of the coronavirus pandemic on the household waste flow during the containment period
}

\author{
Kaizouri Mohamed ${ }^{1, *(D)}$, Mesbahi-Salhi Amina ${ }^{1}$, Madoui Bachir El Mouaz ${ }^{1}$, Bouslama Zihad1(D), Rezaiguia Wafa ${ }^{2}$
}

${ }^{1}$ Laboratory of Ecology of Earth and Aquatic Systems, University of Badji Mokhtar, Annaba, 23052, Algeria.

${ }^{2}$ University of Mohamed cherif Messaadia, Souk-Ahras, 41043, Algeria.

*Correspondence: mohamed.kaizouri@univ-annaba.org

Received: February 2, 2021 Accepted: June 9, 2021

\begin{abstract}
The first COVID-19 case in Algeria, was registered on February 25, 2020, it concerns an Italian national. On November 5,2020 , the total number of infected persons reached 60169 cases and keeps on rising to the point that the curve does not follow the normal law. The present work tries to illustrate another implication caused by the coronavirus pandemic. We focus on the amount of waste produced during the containment caused by the coronavirus epidemic. Targeting three engineered landfill centers (ELCs) located in northeastern Algeria occupying three important wilayas (states) that are Guelma, Eltaref and Annaba, in different population densities. A variable trend increase in household waste quantity is determined during this study. Guelma shows an increase of about $20 \%$, however, Eltaref shows an increase of $11 \%$, while Annaba shows an increase of about 14\%. An increase of the quantities of waste entering the landfills during the pandemic, which will have enormous impacts on technical management, on the leachate flow with its heavy environmental impacts and which will cause an early saturation of the cells, especially with the stopping of the recycling process due to security measures. This study highlights the need to re-examine the current management system in order to better manager similar crises in the future.
\end{abstract}

Keywords: Coronavirus pandemic, COVID-19, Household waste, Landfill.

\section{Introduction}

The whole world is undergoing an acute health crisis never seen since the Spanish flu (1918). The novel coronavirus disease (COVID-19) is an acute respiratory infection caused by the newly discovered coronavirus. In March 2020, WHO has classified it, as a Public Health Emergency of Concern (PHEIC) [1]. Currently there is no adequate antiviral medication or vaccine available at this time. The first signs show that the virus is zoonotic and bats are the reservoirs of the virus [1].

On February 25, Algeria recorded the first case in the living base at Hassi Messaoud in the wilaya (state) of Ouargla [2]. From March 02, 2020, a new outbreak was discovered in the wilaya (state) of Blida following an alarm raised from France after the confirmation of two cases of COVID-19; these were two Algerians, residing in France who had come to Algeria. Since then, the epidemic has spread throughout the national territory with predominance in the Northern Wilayas in Where densely populated is localized [2]. Algeria has registered on November 5, 2020 the number of cases attained 60169 confirmed and as everywhere else in the world, the incidence follows an exponential curve [3].

During this pandemic, Algeria has adopted important measures to ensure a rational management of the health, and socio-economic situation. These measures have resulted in the full mobilization of the Algerian government, and all the actors involved in the response [3]. First and foremost all health personnel, prevention, active surveillance, the closure of educational establishments and schools of all kinds, places of prayer (mosques), early detection by PCR, rapid management of cases with the therapeutic protocol based on the hydroxychloroquine-azythromycin association [3]. In addition, confinement from March 22 to June 14, partially progressive according to the prevalence of the disease in the different regions [4].

Once confined, people's purchasing and food consumption behavior has undergone a profound change, with the use of online shopping and home delivery of essential products such as: food and sanitary disinfection products (hydroalcoholic gel, toilet paper, etc.). Hyun [5] reports that panic buying caused by the coronavirus pandemic has led to irrational storage of food and other grocery products, due to fears of food shortages. The demand for these packaged products has had an increase in several countries. South Korea which recorded $92.5 \%$ of online food shopping and $44.5 \%$ 
on basic necessities was recorded compared to the previous year during the pandemic [5].

Hari Bhakta et al, also reported an increase in online purchases in several countries, such as Vietnam (57\%), India (55\%), China (50\%), Italy (31\%) and Germany (12\%). During the containment period [6]. The increased demand for plastics is mainly limited to food and grocery packaging in film, multilayer plastics and is a major concern due to their single use and low recyclability [7].

Van Fan et al, provided an update in work on the impact of COVID-19 on the change in quantity, composition, time, frequency and distribution of household waste and on the risk of infection [8].

Coronavirus has changed the dangerousness of household waste and has become infectious, not only in medical waste, but also in household waste also, because coronavirus can persist in plastic, metal and cardboard (waste component) for hours or days [9]. Given the new data, infectious waste is not only found in hospitals and health centers, or medical waste but even people with minor or asymptomatic symptoms also generate virus-laden waste (masks, gloves, discarded tissues, etc.) from their homes [6]. This puts the lives of workers responsible for waste management and handling at risk, especially in developing countries like our context, where sorting is done by hand and rag pickers and collectors are not equipped with adequate personal protection [6].

However, a very interesting study by Jribi et al. also reported an increase in the production of household food waste during total containment in Tunisian context, with an online survey conducted during the first 2 weeks of containment period. The closures and panic buying caused by COVID-19 have led people to store perishable foodstuffs without considering their shelf life. Jribi et al. report in their interesting study that the coronavirus crisis has motivated an amplify in public knowledge of food waste due to food supply shortages occurring [10].

The objective of this study is to contribute to know the flow of household waste produced during the containment period induced by COVID-19, in an Algerian context (Eastern of Algeria) in order to examine the trends or any other implications of the pandemic coronavirus on the field of household waste management.

\section{Materials and Methods}

The COVID-19 pandemic has affected all aspects of human life, to the extent that it has put everything in difficulty: health, employment and working conditions, schooling and social interactions, transportation, access to state and private institutions, communication and information from relevant services, making it a real challenge to conduct research. Especially in this time of contagion; where the incidence curves of the disease are exponentially rising nationally and internationally [11]. Fortunately, for this reason there is a daily updated epidemiological map, established by the Ministry of Health to facilitate data retrieval: reported, cured, deceased, hospitalized and the prevalence of the disease in the different wilayas (states) and this until November 5, 2020.

A look at the literature would be important in order to feed into and shed light on what is already being done in the research equation (impact of COVID-19, household waste). Apart from a few very important articles that were close by, the research was oriented much more towards medical waste management in view of the new data, the behavior and characteristics of coronavirus and its heavy socio-economic impact.

For the rest of the information, a field trip would be necessary where very important data were discovered during this survey, data that will build this study and give it meaning; based on the quantification of household waste collected monthly in the three-engineered waste landfills in the eastern Algerian area occupying three important states (Guelma, ElTarf and Annaba). Very detailed data concerning the flow of household waste entering the landfills were taken directly from the technical services of the centers.

We have chosen these three centers because they fit in our study and monitoring area (the Algerian East). Our mission focuses on the production and management of household waste. In addition, the three centers are controlled landfills, where we can have accurate statistical data that allow us to build correct scientific studies.

Monthly monitoring of the filling of the waste collection cells at the ELCs (1,2 and 3) concerned by our study, carried out during the year 2020, in order to estimate the potential lifespan of the bins and its relationship with the quantity of waste collected daily.

After data collection, statistical analysis was performed using Excel 2013 software to plot the graphs and visualize the collected results to track trends and flows of household waste entering and being buried at the various ELCs in question. 


\section{Description of the study area}

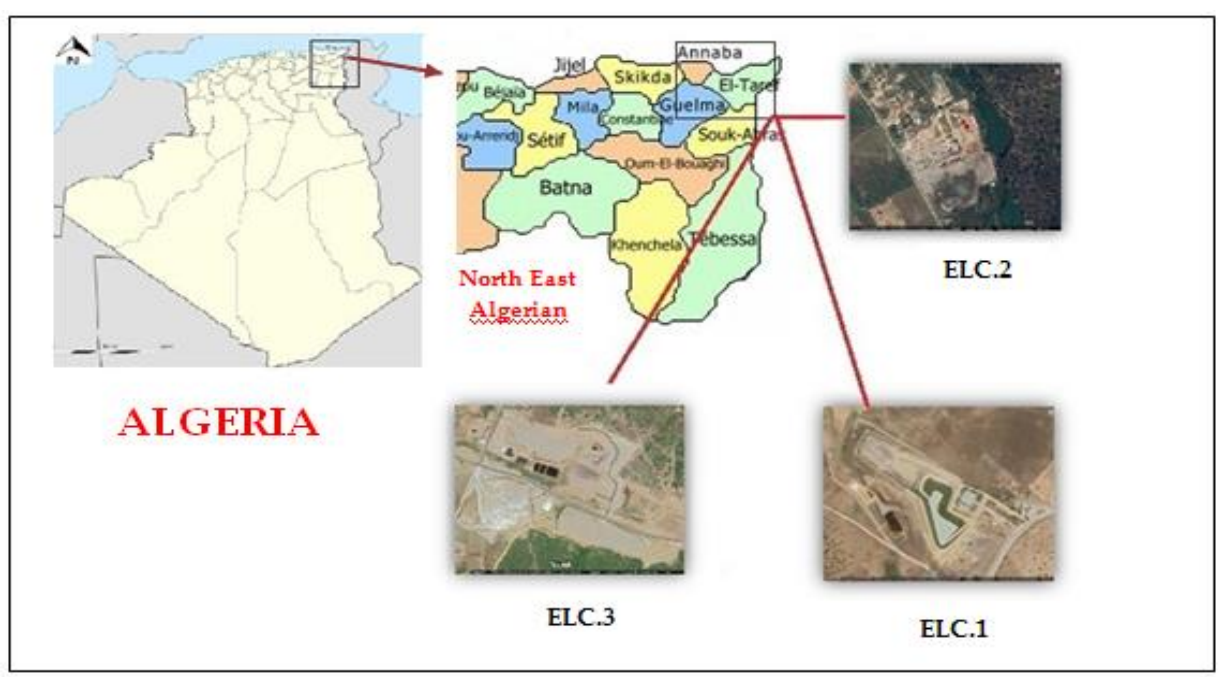

Figure 1. Geographic location of the three engineering land centers (ELCs) (Google Earth).

The Algerian East constitutes our study area, composed of 16 wilayas (States), three of which were selected for analysis namely: Guelma, Eltaref and Annaba (Figure 1).

The wilaya of Guelma is located in the North-East of the country and constitutes, from a geographical point of view, a meeting point, even a crossroads between the industrial poles of the North (Annaba - Skikda) and the exchange centers in the South (Oum-El-Bouaghi and Tébessa), in addition to the proximity of the Tunisian territory in the East. It covers an area of $3686.84 \mathrm{~km}^{2}$ and has a population (Estimated at the end of 2009) of 594079 inhabitants distributed differently in these 34 municipalities [12]. The engineered landfill center (ELC.1) of Guelma is located at the level of Bouguerguer, at $5 \mathrm{~km}$ in the Northeast of the chief town of the Wilaya; the center includes two cells, one of which is already filled [12].

The wilaya of Eltaref is located at the extreme Northeast of Algeria, with an area of $3,339 \mathrm{~km}^{2}$ and a population of about 411,784 inhabitants in 2011 distributed in these 24 communes. It is bounded by the Algerian-Tunisian border to the east, and to the west by the wilaya of Annaba and to the south by the wilayas of Guelma and Souk-Ahras, and to the north by the Mediterranean Sea with a coastline of about $90 \mathrm{~km}$ [12]. The (ELC.2) of Eltaref is located at the level of Elmetroa at 04 $\mathrm{km}$ southeast of the chief town of the wilaya. It has only one cell currently in operation.

The wilaya of Annaba is the third main city after the capital Algiers and Oran. It is the fourth city of Algeria in number of inhabitants, with nearly 609499 inhabitants in its agglomeration. It extends over $1439 \mathrm{~km}^{2}$ or $0.06 \%$ of the national territory, and a Mediterranean coastline of nearly $80 \mathrm{~km}$, it has 12 municipalities including Annaba the city itself has 257359 inhabitants [13] or $42.22 \%$ of the total population of the Wilaya. A volume of population generates household waste, estimated in 2006 between $91 \mathrm{t} / \mathrm{d}$ and $130 \mathrm{t} / \mathrm{d}$ of solid urban waste [14]. The (ELC.3) of Annaba is located in Elguelta Elzarga, $13 \mathrm{~km}$ from the capital of the Wilaya of Annaba. It includes 5 cells, 4 of which are already closed.

Focusing on the three technical landfill sites for household waste in these wilayas, in order to examine the flow and trends in the quantities of waste entering (Table 1).

Table 1. Presentation of the three-engineered landfill centers (ELCs).

\begin{tabular}{llllll}
\hline $\begin{array}{l}\text { Landfill } \\
\text { centers }\end{array}$ & $\begin{array}{l}\text { Wilaya } \\
\text { (State) }\end{array}$ & $\begin{array}{l}\text { Municipalities } \\
\text { connected }\end{array}$ & Location & $\begin{array}{l}\text { Opening } \\
\text { date }\end{array}$ & Average t/d \\
\hline ELC & Guelma & 13 & $\begin{array}{l}36^{\circ} 29^{\prime} 12.2^{\prime \prime} \mathrm{N} \\
7^{\circ} 28^{\prime} 19.6^{\prime \prime} \mathrm{E}\end{array}$ & $\begin{array}{l}\text { January } \\
2012\end{array}$ & 210 \\
$\begin{array}{l}\text { Bouguerguer } \\
\text { ELC }\end{array}$ & & $36^{\circ} 43^{\prime} 29.5^{\prime \prime} \mathrm{N}$ & January & 37 \\
Elmatrouha & Eltaref & 6 & $8^{\circ} 17^{\prime} 55.2^{\prime \prime} \mathrm{E}$ & 2011 & \\
ELC & & & $36^{\circ} 49^{\prime} 14.2^{\prime \prime} \mathrm{N}$ & March & 405 \\
Elguelta zarga & Annaba & 4 & $7^{\circ} 37^{\prime} 18.6^{\prime \prime} \mathrm{E}$ & 2010 & \\
\hline
\end{tabular}




\section{Weight of waste and main control issues}

Vehicles transporting waste entering the landfill sites will be weighed loaded and unloaded at their exit, using a scale. A tolerance for empty weighing may be allowed for vehicles with regular use. Each vehicle entering the ELC will receive a control ticket for the weighing, on this ticket will be noted all the necessary information (tonnage, date, place, etc.) as shown in (Figure 2), in order to calculate the statistics of each separate municipality. The subject of this work is whether coronavirus pandemic has brought about changes in the field of household waste management.

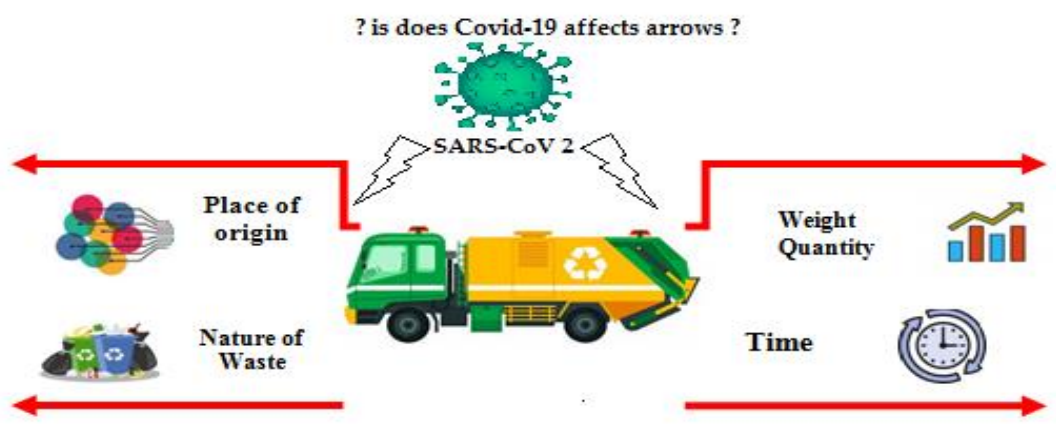

Figure 2. Main axes of waste flow control at the ELCs (Design. Kaizouri).

\section{Results and Discussion}

Amount of household waste received (2017-2020) shown in (Table 2).

The total amount of waste landfilled in the three ELCs in question from January 2017 to December 2020, as

Table 2. Amount of household waste generated in 2017/2020 (expressed in tons).

\begin{tabular}{llll}
\hline & ELC.1 (Guelma) & ELC.2 (Eltaref) & ELC.3 (Annaba) \\
\hline 2017 & 62688.59 & 11968.83 & 87890.72 \\
2018 & 64415.02 & 12838.58 & 89938.01 \\
2019 & 66385.06 & 13570.46 & 92508.69 \\
2020 & 69895.38 & 14958.67 & 96875.84 \\
\hline
\end{tabular}

\section{Waste from the first month of containment, (March 2020)}

compared to the previous month (February). This increase depending on the popular volume of each Wilaya. However, a remarkable correlation between the rates of increase ranging, between 13 and $15 \%$ : ELC.1 of Guelma marked an increase of 791.28 tons, or $14 \%$ increase, while the ELC. 2 of Eltaref marked in turn 164.03 tons, or $15 \%$ increase and finally the ELC.3 of Annaba which recorded 1494.35 tons with 13\% increase. However, in the previous year (2019), there was an increase of only $6 \%, 4 \%$ and $3 \%$ for the three-landfill centers respectively in the same period (Figure 3).
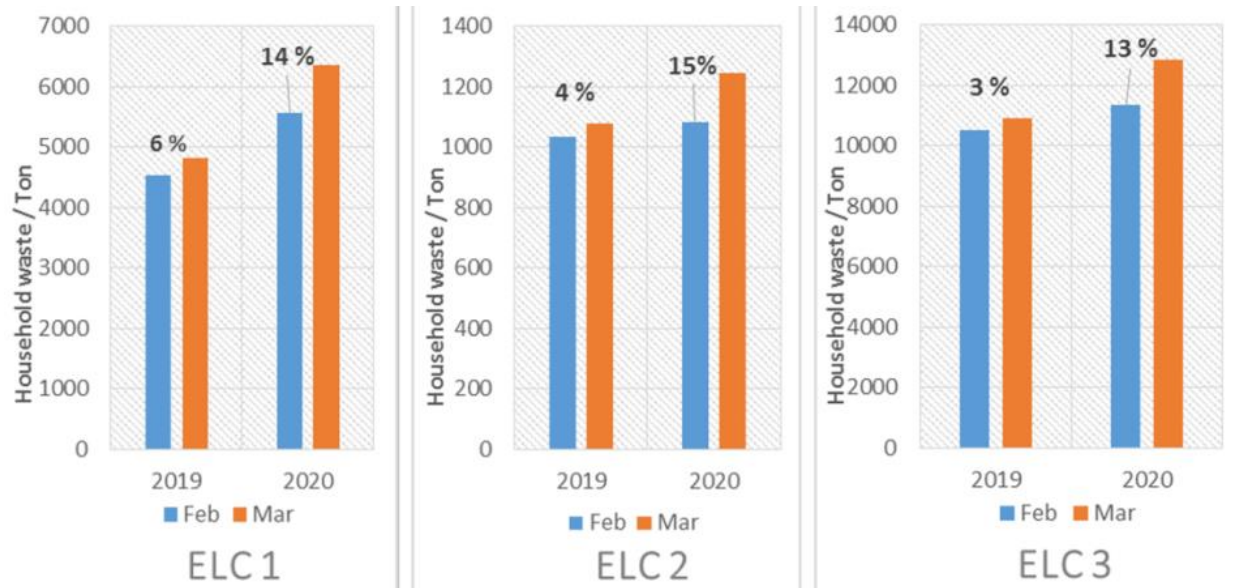

Figure 3. Amount of household waste generated the first month of containment compared with previous month (February, March 2020) all compared to the same period of the previous year (2019).

A considerable increase was recorded in the three landfill centers, from the first month of confinement (March). 


\section{Waste generated during containment (March to June)}

A considerable increase in the production of household waste recorded during the containment period in the three landfills in question, with 3549.6 tons, or a $20 \%$ increase in the first center (ELC from Guelma) compared to the same period of the previous year. Whereas between the period 2018 and 2019 there is no significant difference, with an increase of only 1\%. In the second center (ELC from Eltaref); an 11\% increase in tons with 581.7 tons in the period in question against $5 \%$ between the period from 2018 to 2019. While the third center (ELC from Annaba) recorded an additional quantity of $6,298.03$ tons, a $14 \%$ increase compared to the same period of the previous year (2019), compared to an increase of $5 \%$ between the period 2018 and 2019 (Figure 4).

The study area recorded an average increase of 15\% during the containment period (March to June 2020) compared to the same period in 2019. A result or finding of increase appears similar with other work such as: in Singapore. The average of daily waste collected increased by 3\% during the containment period from April 7 to June 1, 2020 [15]. In the city of Brno in the Czech Republic, an increase in the amount of waste is visible during containment (March 2020), then a decrease when the containment measure is lifted, total waste quantity is generally constant between 2019 and 2020 [8]. On the other hand, Sarkodie proved that in Milan (Italy), the introduction of strict containment led to a $27.5 \%$ decrease in total waste production [16].

Between, an increase and a decrease in the quantities of waste generated during the containment. Several studies have attempted to examine the impact of the coronavirus pandemic in the field of waste management. The majorities of which, including ours, report an increase in the flow of household waste, which is related to multiple factors: the eating and behavioral habits of societies, the degree of progress in the field of waste management, and the level of waste management, panic buying caused by the media and the health situation (the spread of the virus) etc.

A more precise and detailed evaluation in our context would be indispensable in comparison with previous years and particularly the evolution of the composition, quantification and recyclability of waste in order to arrive at a global model. The latter will be the basis of any policy or plan to improve the context of household waste management, especially in developing countries.

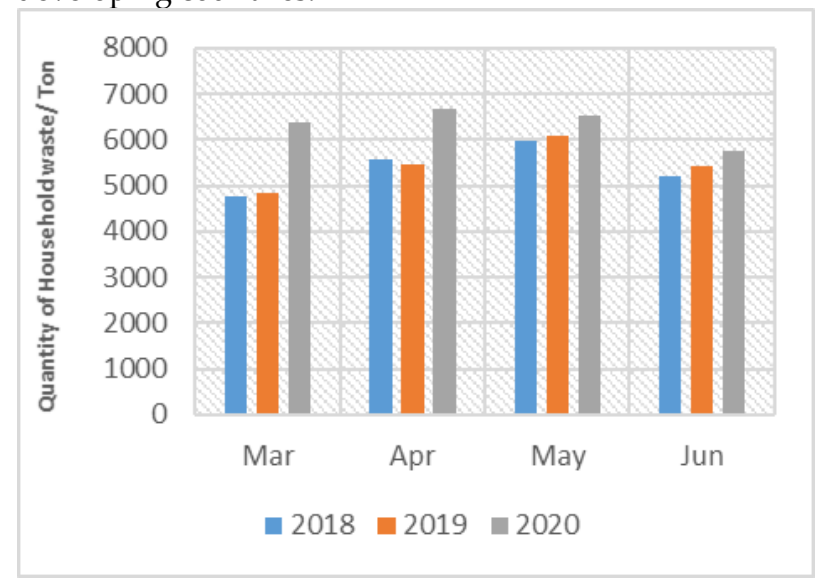

(a)

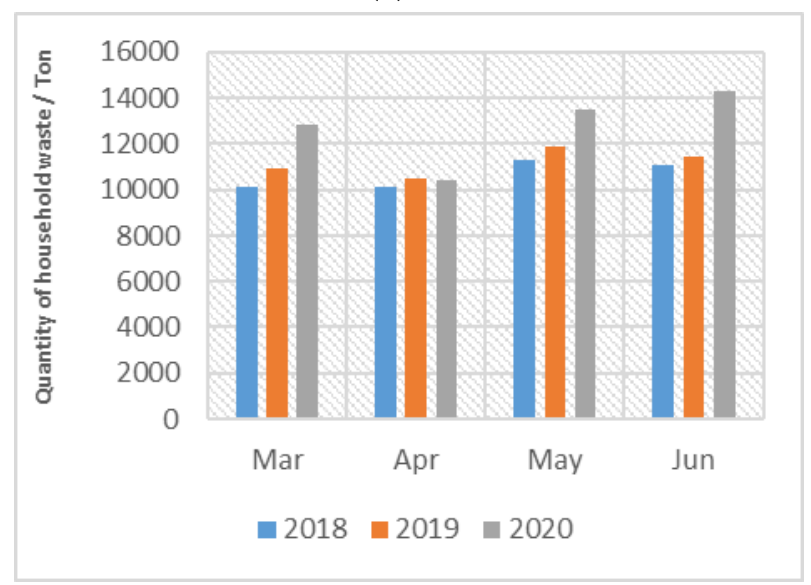

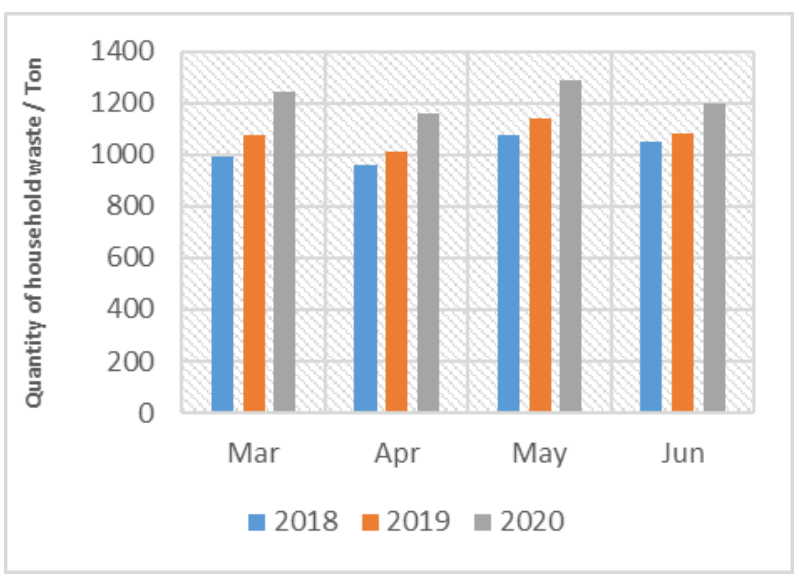

(b)

(c)

Figure 4. Amount of household waste generated during the containment period (March to June) of 2020 compared to the same period of two previous year $(2018,2019)$ with: (a) ELC.1 from Guelma (b) ELC.2 from Eltaref (c) ELC.3 from Annaba. 


\section{Other pandemic implications of the pandemic include Early saturation of cells}

Such an increase in waste quantities could not only affect the cost of material and personal energy management. However, it will also decrease the potential lifetime of the cells as shown in (Figure 5), and the volume pressure would be even more critical with the cessation of the recycling process. Since the infectious hazardousness of the waste has been updated with COVID-19 and remains pathogenic "the waste contains non-medical and household products such as masks, gloves, thermometers, disinfectants and cleaning products, toilet paper and food [16].

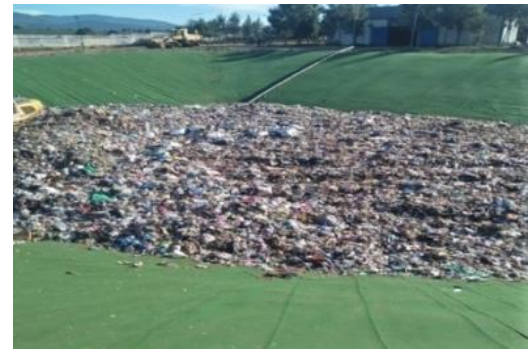

(a)

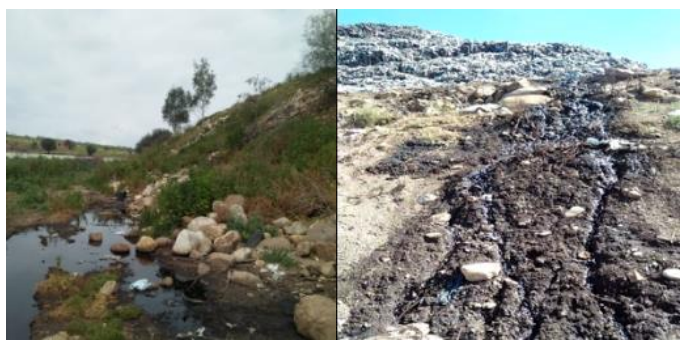

(d)

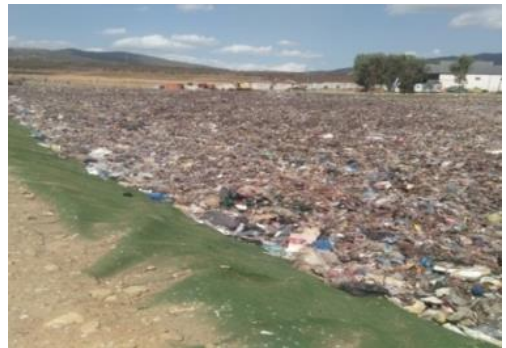

(b)
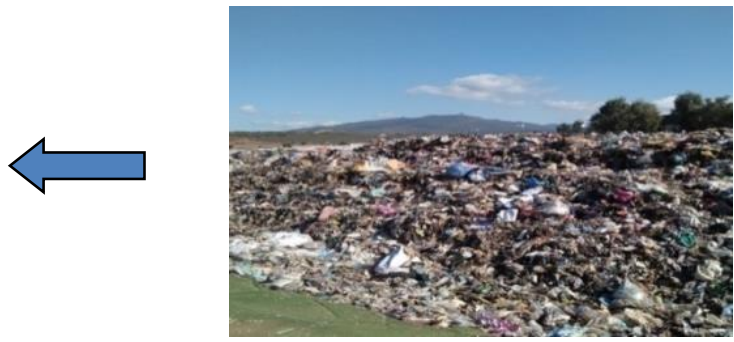

(c)

Figure 5. The voluminous pressure of waste on the cells (ELC.1): (a) Taken in 02/03/2020; (b) Taken in 02/03/2020; (c)Taken the 29/10/2020 (the heightening); (d) Leachate overflow.

\section{Leachate Overflow}

The successive heightening is a temporary measure to receive more quantities of waste, a solution to save space and time, but it will provoke a dangerous phenomenon, which is the overflow of the leachate from the cells. Which will have a heavy environmental impact, threatening the soil and water resources, since the leachate can contain pollutants and contaminants in high doses, such as pathogenic germs [17], in addition, it may also contain heavy metals, toxins, which induce significant micro-toxicity and phytotoxicity putting the surrounding fauna and flora at a real risk [18].

As the engineered landfill center (ELC.1), constructed on a small hill, at the extreme of an agricultural land, which becomes a victim of this installation, even the receiver of overflow of the leachates. In addition, with the absence of a system of recovery of these leachates that overflow, the neighboring agricultural land remains the main receiver of a big polluting load. The report could be heavy by affecting the environmental health of the place. A major crying also, that these leachates reaches the river of Seybouse at 740,73 m, this last one constitutes the major source of the watering of the agricultural lands of the region of Guelma.

\section{Conclusions}

As of May 2020, one third of the world's population is under containment result to the coronavirus an unprecedented health crisis. A new coronavirus disease, officially named COVID-19 by the World Health Organization (WHO), has caused a pandemic with dramatic and changes in many areas of human life, with hundreds of victims [19].

Algeria was not spared from the world, and the wilaya (state) of Blida was the starting point of the epidemic. Since then, Algeria has adopted a strategy of early detection, reporting, isolation and treatment, starting with the declaration of the first case, imported from Italy. On November 5,2020 the number of COVID-19, cases reached 60169, of which 41244 
were cured and 2011 deaths [4]. Radical decisions have been taken to avoid an exponential spread of the virus. Total or partial containment introduced and tightened as the spread of COVID-19 progressed [20].

In addition to the health consequences, the spread of the COVID-19 virus also has a very significant impact on several economic activities [21]. Since March 11, WHO informs that we are facing a pandemic [22]. This last has caused a panic buying, irrational storage and increased food consumption in several countries are phenomena caused by the coronavirus pandemic [5].

The present study illustrates one of the multiple implications that coronavirus has engendered namely the problems of household waste management among other environmental, technical and financial problems was been relegated, and this, in the Algerian context (Northeast of Algeria). In the three-engineered landfills centers subject of our research, we recorded an increase in the quantity of waste produced during the containment period (March to June) compared to the same period of the previous year: an overall increase of $15 \%$ while the annual increase is limited to $6 \%$. This quantity produced in this period has put enormous pressure not only on the logistic and financial management of the centers but also caused a decrease in the potential life span of the recovery cells, especially with the cessation of material recovery and recycling.

A change in the hazardousness of household waste due to the fact that the coronavirus can persist in plastics, metals and cardboard for hours or days [9], which has meant that the recovery and recycling process has been halted because the health of workers involved in the direct handling of waste takes priority over all other considerations.

The problem is whether the pandemic will last or worsen further with further waves, as the cessation curves become more pronounced day after day. This is the very opportunity to review and re-examine the waste management system not only nationally but also internationally in order to better manage similar crises or prepare for other likely waves.

As a solution, for a problem of quantity of waste produced in Eastern of Algeria we suggest:

- The reduction at the source seems primordial; this comes with awareness campaigns, in order to rationalize the consumption and production of household waste among other economic measures (limitation and organization of purchase, etc.).

- The reduction at the end, by the resumption of the recycling activity with taking all the essential sanitary measures that allows the reduction of the most important quantity of waste.

- The modernization of the household waste management system is much recommended (e.g., installation of large incinerators), which helps to reduce the environmental pressure caused by the quantity of household waste flow.

\section{Acknowledgement}

The authors would like to acknowledge the landfill operators of the three centers subject to our study, especially Mr. Bouaarata Mohamed for providing the insights about the waste management.

\section{Conflict of interest}

The authors declare no conflict of interest.

\section{CRediT author statement}

KM: Conceptualization, Visualization, Software; MSA: Writing- Original draft preparation; MBE: Methodology, Data Curation, Formal analysis; BZ: Data Curation, Supervision; RW: Writing- Reviewing \& Editing.

\section{ORCID}

Kaizouri Mohamed: 0000-0003-1990-4950

Bouslama Zihad: 0000-0002-7420-6840

Rezaiguia Wafa: 0000-0003-3716-6728

\section{References}

[1] Kandel N, Chungong S, Omaar A, Xing J. Health security capacities in the context of COVID-19 outbreak: an analysis of international health regulations annual report data from 182 countries. Lancet 2020;395(10229):1047-1053. https://doi.org/10.1016/S0140-6736(20)30553-5

[2] World Health Organization (Who). Khelifi H, volumes 1-7. Rapport de situation sur l'epidemie du covid-19 en Algerie (Algerian). Assessed on Aug 30, 2020. https://www.afro.who.int/sites/default/files/2020-09/Sitrep\%20160-28082020.pdf 
[3] Republic of Algeria, Ministry of Population Health and Hospital Reform (MSPRH). Assessed on Nov 6, 2020. http://covid19.sante.gov.dz/carte

[4] Republic of Algeria. Algeria Press Service (APS). Benbouzid a Covid-19: l'Algérie a adopté une stratégie lui permettant de maîtriser la situation (Algerian). Assessed on Apr 26, 2020. http://www.algerie-medinfo.dz/index.php/politique/7731covid-19-1-algerie-a-adopte-une-strategie-lui-permettant-de-maitriser-la-situation

[5] Hyun, MC. Korea sees steep rise in online shopping during COVID-19 pandemic. ZD Net 2020. Assessed on Mar 30, 2020.https://www.zdnet.com/article/justice-department-seizes-fake-covid-19-vaccine-website-stealing-info-fromvisitors/

[6] Sharma HB, Vanapalli KR, Cheela VS, Ranjan VP, Jaglan AK, Dubey B, et al. Challenges, opportunities, and innovations for effective solid waste management during and post COVID-19 pandemic. Resour Conserv Recycl 2020;162(2020) 105052. https://doi.org/10.1016/j.resconrec.2020.105052

[7] Giacovelli, Claudia. Single-use plastics: A roadmap for sustainability (rev. 2). 2018. https://stg-wedocs.unep.org/handle/20.500.11822/25496

[8] Fan YV, Jiang P, Hemzal M, Klemeš JJ. An update of COVID-19 influence on waste management. Sci Total Environ 2021;754:142014. https://doi.org/10.1016/j.scitotenv.2020.142014

[9] Kampf G, Todt D, Pfaender S, Steinmann E. Persistence of coronaviruses on inanimate surfaces and their inactivation with biocidal agents. Journal of Hospital Infection 2020;104(3):246-251. https://doi.org/10.1016/j.jhin.2020.01.022

[10] Jribi S, Ismail HB, Doggui D, Debbabi H. COVID-19 virus outbreak lockdown: what impacts on household food wastage?. Environ Dev Sustain 2020;22(5):3939-3955. https://doi.org/10.1007/s10668-020-00740-y

[11] Cartwright E, Luong TA, Payne J, Virmani S. The economic impact of the coronavirus pandemic for leicester 2020. https://papers.ssrn.com/sol3/papers.cfm?abstract id=3622981

[12] National Agency for the Development of Investments (Andi). The borough of Guelma. Volumes 1- 19. Presentation of the wilaya (borough)2015. Assessed on Sep 09, 2020. http://www.andi.dz/PDF/monographies/Guelma.pdf.

[13] Republic of Algeria, National statistics office (ONS). Global Population and Housing Census (RGPH); 2008 (Algerian). Assessed on Oct 6, 2020. https://www.ons.dz/spip.php?rubrique182

[14] Hamza, Cheniti. La gestion des déchets urbains solides cas de la ville d'Annaba. Annaba : University Badji Mokhtar; 2014 (Algerian). https://biblio.univ-annaba.dz/wp-content/uploads/2015/06/These-de-CHENITI-Hamza.pdf

[15] Low, DW, A Koh. Singapore's food delivery surge during lockdown highlights waste problems 2020. https://www.bloomberg.com/news/articles/2020-06-24/singapore-binges-on-plastics-ordering-food-during-viruslockdown .

[16] Sarkodie SA, Owusu PA. Impact of COVID-19 pandemic on waste management. Environ Dev Sustain 2020;26:1-10. https://doi.org/10.1007/s10668-020-00956-y

[17] Sillet AA, Royer S, Coque Y, Bourgois, J, Thomas O. Les lixiviats de décharges d'ordures ménagères: genèse, composition et traitements. Déchets Sciences \& Techniques 2001;22:7-11(Français). https://doi.org/10.4267/dechetssciences-techniques.1341

[18] Smaoui Y, Bouzid Y. Déchets du centre d'enfouissement technique de Sfax (Tunisie): nature, composition et traitement. Déchets, Sci Tech 2019;82 (Tunisien).https://doi.org/10.4267/dechets-sciences-techniques.4207

[19] Ramteke S, Sahu BL. Novel coronavirus disease 2019 (COVID-19) pandemic: considerations for the biomedical waste sector in India. Case Studies in Chemical and Environmental Engineering 2020;2:100029.

https://doi.org/10.1016/j.cscee.2020.100029

[20] Wesdorp ICE, Dekker W, Festen HPM. Efficacy of famotidine $20 \mathrm{mg}$ twice a day versus $40 \mathrm{mg}$ twice a day in the treatment of erosive or ulcerative reflux esophagitis. Dig Dis Sci 1993;38(12):2287-2293.

https://doi.org/10.1007/BF01299910

[21] Armand TK. Effets du Covid-19 sur la consommation des ménages à Bukavu 2020 (Congolais). 
Mohamed et al. I Study of three engineered landfill centers in eastern of Algeria

https://www.researchgate.net/profile/Armand-Thamba/publication/340819633 Effets du_Covid-

19 sur la consommation des menages a Bukavu/links/5e9f6dda4585150839f3fa37/Effets-du-Covid-19-sur-laconsommation-des-menages-a-Bukavu.pdf

[22] World Health Organization (WHO). Coronavirus disease (COVID-2019) situation reports. Assessed on Nov 14, 2020. https://www.who.int/emergencies/diseases/novel-coronavirus-2019/situation-reports 